(3)

Volume 22, 2019

\title{
THE IMPACT ON PUbLiC TRUST OF IMAGE MANIPULATION IN SCIENCE
}

\author{
Francisco López-Cantos Universitat Jaume I, Castellón, Spain flopez@uji.es
}

\begin{abstract}
Aim/Purpose

In this paper, we address the theoretical challenges today's scientific community faces to precisely draw lines between true and false pictures. In particular, we focus on problems related to the hidden wonders of science and the shiny images produced for scientific papers or to appeal to wider audiences.

Background As rumors (hoaxes) and false news (fake news) explode across society and the current network, several initiatives using current technology have been launched to study this phenomena and limit the social impact. Over the last two decades, inappropriate scientific behavior has raised more questions about whether some scientific images are valid.

Methodology This work is not about analyzing whether today's images are objective. Instead, we advocate for a general approach that makes it easier to truly believe in all kinds of knowledge, scientific or otherwise (Goldman, 1967; Goldman, \& Olson, 2009). This need to believe is closely related to social order (Shapin, 1994).

Contribution We conclude that we must ultimately move away from older ideas about truth and objectivity in research to broadly approach how science and knowledge are represented and move forward with this theoretical approach when communicating science to the public.

Findings Contemporary visual culture suggests that our world is expressed through images, which are all around us. Therefore, we need to promote the reliability of scientific pictures, which visually represent knowledge, to add meaning in a world of complex high-tech science (Allamel-Raffin, 2011; Greenberg, 2004; Rosenberger, 2009). Since the time of Galileo, and today more than ever, scientific activity should be understood as knowledge produced to reveal, and therefore inform us of, (Wise, 2006) all that remains unexplained in our world, as well as everything beyond our senses.
\end{abstract}

Accepting Editor Eli Cohen | Received: June 17, 2019 | Revised: July 15 July 24, 2019 |

Accepted: July 26, 2019.

Cite as: López-Cantos, F. (2019). The impact on public trust of image manipulation in science. Informing Science: the International Journal of an Emerging Transdiscipline, 22, 45-53. https://doi.org/10.28945/4407

(CC BY-NC 4.0) This article is licensed to you under a Creative Commons Attribution-NonCommercial 4.0 International License. When you copy and redistribute this paper in full or in part, you need to provide proper attribution to it to ensure that others can later locate this work (and to ensure that others do not accuse you of plagiarism). You may (and we encourage you to) adapt, remix, transform, and build upon the material for any non-commercial purposes. This license does not permit you to use this material for commercial purposes. 
Recommendations In journalism, published scientific images must be properly explained. Journalfor Practitioners ists should tell people the truth, not fake objectivity.

Recommendations Today we must understand that scientific knowledge is mapped, simulated, and for Researchers accessed through interfaces, and is uncertain. The scientific community needs to approach and explain how knowledge is represented, while paying attention to detail.

Impact on Society It is sometimes hard to build data that represents scientific truth. More so, data could also be designed to intentionally fake knowledge. This leads to huge consequences when it comes to how the public understands science.

Future Research In today's expanding world, scientific research takes a more visual approach. It is important for both the scientific community and the public to understand how the technologies used to visually represent knowledge can account for why, for example, we know more about electrons than we did a century ago (Arabatzis, 1996), or why we are beginning to carefully understand the complexities and ethical problems related to images used to promote knowledge through the media (see, i.e., López-Cantos, 2017).

Keywords fake pictures, scientific fraud, scientific pictures, public understanding of science, science communication, science journalism

\section{FAKe Pictures and Public Understanding of Science}

There's nothing new about falsified accounts in science and journalism. However, photos today are routinely re-touched in all scientific areas and journalistic practices. Digital technology makes it easier for manipulated pictures to pass unnoticed. There have been well-known cases of falsified images throughout history, especially photographs of politicians such as Stalin, Mao, and Castro. In fact, there is a photo of Abraham Lincoln that was rendered to make him look more heroic by substituting another person's body for his (see Farid, 2018, for examples). In a digital and multimedia environment such as ours, where information is sent very quickly and on a global scale, it is not surprising that the massive spread of fraudulent content across all media has triggered alarms.

As rumors (hoaxes) and false news (fake news) explode across society and the current network, several initiatives using current technology have been launched to study this phenomena and limit the social impact (Balmas, 2014; Lazer et al., 2018; Tandoc, Lim, \& Ling, 2018; Vargo, Guo, \& Amazeen, 2018). It is a challenge that questions the foundations of our current societies, some of which are already heading toward a new Post-truth Era (D'Ancona, 2017; Keyes, 2004; Mihalidis \& Viotty, 2017; Sismondo, 2017).

The University of Warwick conducted a study in which 700 participants were asked to identify fake pictures. Through naked eyes, these people were able to detect approximately 30 to 40 percent of the manipulated images (Nightingale, Wade, \& Watson, 2017). In the fields of journalism and public communication of science, fake news continues to spread, with efforts redoubled to analyze its impact as the latest epidemic (Kucharski, 2016).

It can be harder to detect which scientific images have been altered. However, it is very noticeable in some cases. For example, the University of Tokyo's Shigeaki Kato Laboratory analyzed images from a 2009 article published in Nature, which has for years been considered a reputable journal in the research community. In that one article, more than 20 scams were found (see full retracted Kato's papers list at http://katolab-imagefraud.blogspot.com). Research on the use of images in biomedicine publications (based on PubMed data) has found that in some specific research areas, such as oncology, $25 \%$ of all published articles containing images from experiments with gels were fake (Oksvold, 2015). Another study on a random sample of 1,364 articles from 451 PubMed journals 
found about $6 \%$ contained clearly fraudulent images (Bucci, 2018), even though only a few of the possible manipulations were analyzed.

According to the National Science Foundation (Fischer, 2016), when it comes to inappropriate research practices, it is possible to distinguish the types of manipulation used in conducting research and recording results: material manipulation; changes in processes or research equipment; data or result omissions; and plagiarizing other people's ideas, processes, or results. At minimum, this behavior is reprehensible. In some cases, it is a matter of ignorance or carelessness. However, most of the time, it is intentional and, therefore, punishable. The fact that it prevails within the scientific community makes detecting fraud a priority in both studies as well as mobilizing resources to combat it (Kroll, 2011).

The focus of this work is to advocate for a general approach that makes it easier to truly believe in all kinds of knowledge, scientific or otherwise (Goldman, 1967; Goldman, \& Olson, 2009). The need to believe is closely related to social order (Shapin, 1994). It is sometimes hard to build data that represents scientific truth. More so, data can also be designed to intentionally fake knowledge. This leads to huge consequences when it comes to how the public understands science.

Contemporary visual culture, in which the world is expressed through images, requires that their reliability be confirmed. The scientific community needs to approach and explain how knowledge is represented, while paying attention to detail. In this paper, we address the theoretical challenges today's scientific community faces to properly define truth, especially whether images and pictures are authentic and original. We support a generic approach based on the theory of scientific knowledge, while stressing the need to integrate truth in science and technology research and move away from older ideas about truth and objectivity.

\section{IMAGE MANIPULATION, OBJECTIVITY, AND SCIENTIFIC FRAUD}

Throughout history, scientific images have been used to influence culture. Since the sixteenth century, with Fuchs and Vesalius's illustrated works, the scientific community has commonly used visuals to faithfully represent knowledge, start conversations, and gain consensus. For example, the Royal Society records show that at regular meetings, members decided on the most appropriate and relevant illustrations to include in articles published in Philosophical Transactions, as "a valuable way to establish, examine, and share knowledge about a scientific object" (Kusukawa, 2011, p. 195). However, outside of taking responsibility to find the best ways to generate scientific knowledge, image use became regarded as a way to objectively reproduce nature. Soon images were considered evidence, especially after Galileo drew the moon using a telescope he developed to demonstrate his mathematic skills. Like Galileo, Descartes used illustrations, images, and diagrams in his research to communicate scientific truth (López-Cantos, 2016).

In early investigations, illustrations created using scientific instruments soon became common in research and were considered evidence, as shown by many including Lüthy (2006, p. 97), who noted that: "In the case of most books, once we have read a few lines and looked at a few of the diagrams, the entire message is perfectly obvious. The rest is added only to fill up the paper." In short, visual representation soon became an independent object with which to validate knowledge. Over the next centuries, this feature would strengthen, especially with the invention of photography, which led to virtual witnessing, or "the most powerful technology for constituting matter of fact" (Shapin \& Schaffer, 1985, p. 60).

New recording techniques, as shown in recent photography works (Nikolow \& Bluma, 2008) or cinematography (Kirby, 2011), forever changed culture in all areas. This was especially the case when new technology was developed to represent knowledge (such as X-rays, radar, sonar, MET, PET, satellite images). This strengthened the use of images as proof, as shown in Rosalind Franklin's photos which captured Watson and Crick's discovery of DNA structure. Photography ushered in an era in which visual representations were valued as evidence through virtual witnessing, and which Daston 
and Galison (2007) named the Mechanical Objectivity Era. Between photography and scientific tools, a highly visual culture began to form. It was a hope of many, including physiologist Marey, who "dreamed of a wordless science" and concluded: "There is no doubt that graphical expression will soon replace all others whenever one has at hand a movement or change of state, in a word, any phenomena."

New representation techniques immediately emerged in scientific work. Although there were a few years in which illustrations coexisted with photographic reproductions, drawings were soon deemed outdated and replaced by new mechanical processes of the times (Tresch, 2007). Photographic techniques expanded and were soon considered the best technology to reproduce scientific activity. First, photography diminished the credibility of any image or illustration that seemed the least bit artistic. Second, because they appeared to capture the truth, photos allowed the scientific community to achieve objectivity at that time, and thus were considered independent from their subject matter. Since then, the use of photography has facilitated major advances in all scientific fields such as those achieved by Robert Koch in bacteriology, which definitely strengthened the validity of microscopic images as scientific evidence. Since then, the trend of see and believe (Hüppauf \& Weingart, 2008, p. 11), or the need for verification through images, grew into the twentieth century, which eventually led to changes in how we view scientific works and culture overall.

Just as we understand it today, as Galileo understood it in his time, visual representation using photographs served as oculata certitudine, or visual certainty. However, in the early twentieth century, claims that photos were independent from what they stood for became loaded with theory as we entered the realm of the invisible. With cutting-edge imaging technologies that allow us to explore beyond what can be seen by the human eye, we have entered the era of visual witnessing, the theory of which applies the revolutionary works of the 1960s to Kuhn or Latour's history of science and sociology.

Today, there is more research that questions the usefulness and related ethical problems with new big data techniques (i.e., Leonelli, 2014; Zwitter, 2014), noting the tremendous resources needed to manage these huge databases. To quote Latour and Woolgar (1979), "Numbers, numbers, numbers..." With each new era, such as the Big Data Era, come new myths, because, as they said, "Change the instruments, and you will change the entire social theory that goes with them."

\section{DAta Pictures, OBJeCtivity, ANd Scientific Fraud}

The current imaging process is a series of successive phases. It starts the moment light interacts with a scene, after which it is captured by a sensor then encoded in as binary data. It is then recorded in a digital file as a specific format (i.e., JPEG, TIFF, BMP, or formats such as AVI, QuickTime). In each of these successive phases, we need to certify the authenticity, or verify that the image has not been manipulated (not fake). It is easy to confirm on site whether a recorded image is valid. However, if the scene's image is too big or small, we need to confirm its validity other ways.

Thanks to cutting edge technology, obtaining scientific images has become a complex process. These images are often unplanned and require significant money and support from the international scientific community. The results are considered effective when many researchers can agree on them. However, even when the systems and processes are carefully observed, the validity of the results and images obtained may still be discussed or thoroughly reviewed. Since the outcomes are driven by technology, they could still fail. Meanwhile, embellishment of scientific images is one of the problems conveyed in the Theory-ladenness (Hanson, 1967), and is a result of methods used to produce scientific knowledge (Knorr-Cetina, 1981), which comprise today's framework for understanding scientific activity (Kuhn, 1962).

Anscombe (1973) questioned the limits of visually represented data. The current problem is that the new promises only go beyond improving the representation value, and intend to complete the old dream that navigators and geographers who charted new territories formed with the first map printings (Ford, 1992, p. 131). During the last century, we transitioned from illustrating worldly objects to 
representing the intangible, and encountered all the related problems along the way (Lynch, 2006). A few decades ago, Heidegger referred to this as The Age of the World Picture, in which the modern world is seen as an image (see Gross, 2006). Over the past decades, Manovich (2002) and others have also thoroughly explored and analyzed the implications and limitations of this age.

By contrast, because we believe what we see with pictures, we reinforce the belief that scientific activity is genuine and honest. In most cases, it is. Nevertheless, the discovery of notorious fakes shows that scientific knowledge is fragile and can be easily utilized to commit fraud.

Recent studies, in which scientists were asked about fraud in their investigations, suggests that $2 \%$ of them have consciously committed some fraud in their careers (Fanelli, 2009). Nevertheless, according to RetractionWatch.com, only 684 out of 800,000 articles were withdrawn in 2015 (Brainard \& You, 2018). Over the last two decades, there has been an increase in the number of cases of inappropriate scientific behavior in which the validity of scientific images has been questioned. Between 1989 and 1999 , it was assumed that there only $2.5 \%$ of the images were fake, and this percentage jumped to an alarming 68\% in a 2007 - 2008 study (Krueger, 2009; Parrish \& Noonan, 2009). Since this was reported a decade ago, the scientific community has followed the Royal Society's long time standard practice of agreeing on the validity of the images. Some of the most prestigious scientific publications, including Nature (2006), are developing guidelines for authors and ethical protocols to avoid publishing altered images. Others, such as Cromey (2013), have focused their research on determining the best practices for producing scientific images.

As Emma Frow concluded in her analysis on the editorial policies of the largest scientific journals, this increase in falsification goes beyond the mere detection of fraud. Normally, scientific journals question the integrity of scientific works: "The current concerns of journal editors revolve less around determining the so-called truth or falsity of digital images and are more about setting norms for image production as a means of safeguarding trust in the published image" (Frow, 2012, p. 29). These editors are well aware of the power and impact of digital technology when it comes to embellishing scientific images. Because effectively analyzing images is a complex process, they now hire experts in forensic imaging to review images and confirm their validity before they are published (Pearson, 2005; Couzin, 2006). Recent editorials in prestigious publications such as Nature or The Lancet have also voiced concern about this phenomenon (Higgins, 2016; Marmot, 2017).

Some of the latest cases are quite dramatic and have revealed more about fraudulent work and the publication of fake research articles. After a thorough investigation, it was discovered that Japanese researchers Sato and Sasai's results were totally fabricated. The case ended when Sasai, an eminent scientist and expert in stem cells, committed suicide. It is likely that Sato also killed himself, because a discovery like this would have meant great dishonor in the Japanese culture (Kupferschmidt, 2018). In any case, beyond the legal consequences that scientific fraud may have for its authors, there are powerful consequences for the scientific community and society overall. According to Ithenticate, the cost of scientific misconduct is estimated to be around 100 billion dollars per year (Ithenticate, 2012).

In sum, this supposedly new Big Data Era version of the oldest techno-neopositivist myth, which has developed over the past decades around the Silicon Valley, and is rapidly promoted by the media as the popular discourse on truth (Gregg, 2015), is not the solution. We must remember that as the body of analyzed data gets bigger, we introduce more biases to the process of capturing scientific pictures and create more problems in validating images. Despite careful use of methods involved, the data pictures obtained are certainly "multifaceted and multitruthed" (Focault \& Meirelles, 2015), and their proper representation only amounts to the degree to which the scientific community examining them agrees on their objectivity. 


\section{CONCLUSION: AN ETHICAL QUESTION CONCERNING RESEARCHERS AND JOURNALISTS}

Resnik (1998) defined the most relevant issues regarding the ethics involved in the public communication of science. We also echo Leibovitz's distinction "between science and ethics by pointing out that science leads to conclusions, while ethics leads to decisions. Conclusions require factual data, in contrast to decisions, which are voluntary choices between alternatives" (see Laslo, Baram-Tsabari, \& Lewenstein, 2011, p. 850). In this sense, there are big differences between how journalists and scientists approach uncertainty. Journalists think their work requires a true attempt to "let the facts speak for themselves" and stick to breaking news the audience cares about to provide this objective fact. However, researchers' work requires time, systematic methods, and transparent accounts (Post, 2015, p. 731). Meanwhile, scientists do not provide absolute answers, but raise more questions because their approach to knowledge is, obviously, uncertain.

As stated above, since the beginning of the twentieth century, how knowledge is visually represented has depended on technical imaging tools designed to explore the realm of the invisible. As a result, visual representation becomes independent from its subject matter because there is longer visible certainty. Whether we invent it, or it is naturally out there, is another metaphysical question we need to ask. Without delving too deeply, this question should probably be approached by examining the problems of life in the postmodern world.

In any case, contemporary visual culture, in which the world is expressed through images, surrounds us. Therefore, we need to promote the reliability of scientific pictures, which visually represent knowledge, to add meaning in a world of complex high-tech science (Allamel-Raffin, 2011; Greenberg, 2004; Rosenberger, 2009). Since the time of Galileo, and today more than ever, scientific activity should be understood as knowledge produced to reveal, and therefore inform us of, (Wise, 2006) all that remains unexplained in our world, as well as everything beyond our senses.

In today's expanding world, scientific research takes a more visual approach. It is important for both the scientific community and public to understand how the technologies used to visually represent knowledge can account for why, for example, we know more about electrons than we did a century ago (Arabatzis, 1996), or why we are beginning to carefully understand the complexities and ethical problems related to images used to promote knowledge through the media (see i.e. López-Cantos, 2017).

To conclude, today we must understand that scientific knowledge is mapped, simulated, and accessed through interfaces, and it is uncertain. In other words, it is conditional and far from how we traditionally conceive truth. The scientific community needs to approach and explain how knowledge is represented, while paying attention details. In journalism, published scientific images must be properly explained as well. Journalists should tell people truth, not fake objectivity.

\section{REFERENCES}

Allamel-Raffin, C. (2011). The meaning of a scientific image: Case study in nanoscience a semiotic approach. NanoEthics, 5(2), 165-173. https://doi.org/10.1007/s11569-011-0123-1

Anscombe, F. J. (1973). Graphs in statistical analysis. The American Statistician, 27(1), 17-21. https://doi.org/10.1080/00031305.1973.10478966

Arabatzis, T. (1996). Rethinking the "discovery" of the electron. Studies in History and Philosopby of Science, Part B: Studies in History and Philosophy of Modern Physics, 27(4), 405-435. https://doi.org/10.1016/S13552198(96)00019-6

Balmas, M. (2014). When fake news becomes real. Combined exposure to multiple news sources and political attitudes of inefficacy, alienation, and cynicism. Communication Research, 41(3), 430-454.

https://doi.org/10.1177/0093650212453600 
Brainard, J. \& You, J. (2018, October 25). What a massive database of retracted papers reveals about science publishing's death penalty' Science. https://doi.org/10.1126/science.aav8384

Bucci, E. (2018). Automatic detection of image manipulations in the biomedical literature. Cell Death and Disease, 9(400), 1-9. https://doi.org/10.1038/s41419-018-0430-3

Couzin, J. (2006). Don't pretty up that picture just yet. Science, 314(5807), 1866-1868. https://doi.org/10.1126/science.314.5807.1866

Cromey, D. W. (2013). Digital images are data: And should be treated as such. In D. Taatjes, \& J. Roth (Eds.). Cell Imaging Techniques. Methods in Molecular Biology (Methods and Protocols), 931, 1-27. Totowa, NJ: Humana Press. https://doi.org/10.1007/978-1-62703-056-4 1

D'Ancona, M. (2017). Post-trutb: The new war on truth and how to fight back. London: Ebury Press.

Daston, L., \& Galison, P. (2007). Objectivity. Brooklyn, NY: Zone Books.

Fanelli, D. (2009). How many scientists fabricate and falsify research? A systematic review and meta-analysis of survey data. PLOS ONE, 4(5), e5738 (1-11). https://doi.org/10.1371/journal.pone.0005738

Farid, B. (2018). Photo tampering throughout history. Retrieved from https://www.cc.gatech.edu/ beki/cs4001/history.pdf

Fischer, P. (2016). New research misconduct policies. National Science Foundation (NSF). Retrieved from https://www.nsf.gov/oig/_pdf/presentations/session.pdf

Focault, B., \& Meirelles, I. (2015). Visualizing computational social science: The multiple lives of a complex image. Science Communication, 37(1), 34-58. https://doi.org/10.1177/1075547014556540

Ford, B. J. (1992). Images of Science: A bistory of scientific illustration. London: British Library.

Frow, E. (2012). Drawing a line: Setting guidelines for digital image processing in scientific journal articles. Social Studies of Science, 42(3), 369-392. https://doi.org/10.1177/0306312712444303

Goldman, A. I. (1967). A causal theory of knowing. The Journal of Philosophy, 64(12), 357-372. https://doi.org/10.2307/2024268

Goldman, A. I., \& Olson, E. J. (2009). Reliabilism and the value of knowledge. In D. Pritchard, A. Millar, \& A. Haddock (Eds.). Epistemic value (pp. 19-41). Oxford: Oxford University Press. https://doi.org/10.1093/acprof:oso/9780199231188.003.0002

Greenberg, J. (2004). Creating the "Pillars": Multiple meanings of a Hubble image. Public Understanding of Science, 13(1), 83-95. https://doi.org/10.1177/0963662504042693

Gregg, M. (2015). Inside the data spectacle. Television \& New Media, 16(1), 37-51. https://doi.org/10.1177/1527476414547774

Gross, A. G. (2006). The verbal and the visual in Science: A Heideggerian perspective. Science in Context, 19(4), 443-474. https://doi.org/10.1017/S0269889706001037

Hanson, N. R. (1967). An anatomy of discovery. Journal of Philosophy, 64(11), 321-352. https://doi.org/10.2307/2024301

Higgins, K. (2016). Post-truth: A guide for the perplexed. Nature: International Weekly Journal of Science, 540(7631), 9. https://doi.org/10.1038/540009a

Hüppauf, B., \& Weingart, P. (2008). Science images and popular images of sciences. New York, NY: Routledge.

Ithenticate (2012). \$100 billion problem: Government duplicate spending. Turnitin. Retrieved from https://wwwithenticate.com/hs-fs/hub/92785/file-16016813-pdf/docs/ithenticate-gov-grants-report.pdf

Keyes, K. (2004). The post-truth era: Dishonesty and deception in contemporary life. New York, NY: St. Martin's Press.

Kirby D. A. (2011). Lab coats in Hollywood: Scientists impact on cinema, cinema's impact on science and technology. Cambridge, MA: MIT Press.

Knorr-Cetina, K. (1981). The manufacture of knowledge. An essay on the constructivist and contextual nature of science. Oxford: Pergamon Press. 
Kroll, J. (2011). Technology for plagiarism detection. International Workshop on Accountability in Science and Research Funding. National Science Foundation (NSF). Retrieved from https://www.nsf.gov/oig/ pdf/presentations/intl workshops/brussels2011/13kroll.pdf

Krueger, J. (2009). Incidences of ORI cases involving falsified images. Office of Research Integrity Newsletter, 17(4), 2-3. https://doi.org/10.1037/e648372011-005

Kucharski, A. (2016). Study epidemiology of fake news. Nature: International Journal of Science, 540(525), Online. https://doi.org/10.1038/540525a

Kuhn, T. S. (1962). The structure of scientific revolutions. Chicago, IL: Chicago University Press.

Kupferschmidt, K. (2018). Researcher at the center of an epic fraud remains an enigma to those who exposed him. Science. https://doi.org/10.1126/science.aav1079

Kusukawa, S. (2011). Picturing knowledge in the early Royal Society: The examples of Richard Waller and Henry Hunt. Notes \& Records: The Royal Society Journal of the History of Science. https://doi.org/10.1098/rsnr.2010.0094

Laslo, E., Baram-Tsabari, A., \& Lewenstein, B. (2011). A growth medium for the message: Online science journalism affordances for exploring public discourse of science and ethics. Journalism, 12(7) 847-870. https://doi.org/10.1177/1464884911412709

Latour, B., \& Woolgar, S. (1979). Laboratory life: The social construction of scientific facts. London: Sage Publishers.

Lazer, D. M. J., Baum, M. A., Benkler, Y., Berinsky, A. J., Greenhill, K. M., Menczer, F., Metzger, M. J., Nyhan, B., Pennycook, G., ... \& Zittrain, J. L. (2018). The science of fake news. Science, 359(6380), 1094-1096. https://doi.org/10.1126/science.aao2998

Leonelli, S. (2014). What difference does quantity make? On the epistemology of big data in biology. Big Data \& Society, 1(1), 1-11. https://doi.org/10.1177/2053951714534395

López-Cantos, F. (2016). Photography in the boundaries of the visible. From Santiago Ramon y Cajal to Cecil Frank Powell. Cogent Arts \& Humanities, 3(1), 1182715. https://doi.org/10.1080/23311983.2016.1182715

López-Cantos, F. (2017). Comunicación pública de la ciencia y ética periodística. La representación del bosón de Higgs. Estudios sobre el mensaje periodístico, 23(2), 1199-1213. https://doi.org/10.5209/ESMP.58040

Lüthy, C. (2006). Where logical necessity becomes visual persuasion: Descarte's clear and distinct illustrations. In S. Kusukawa \& I. Maclean (Eds.), Transmitting knowledge: Words, images and instruments in Early Modern Europe (pp. 97-134). Oxford: Oxford University Press.

Lynch, M. (2006). The production of scientific images. Vision and re-vision in the history, philosophy, and sociology of science. In Visual cultures of science: Rethinking representational practices in knowledge building and science communication (pp. 26-40). Hanover, NH: Dartmouth College Press.

Manovich, L. (2002). Data visualization as new abstraction and anti-sublime. Software Studies Initiative. Retrieved from http://manovich.net/index.php/projects/data-visualisation-as-new-abstraction-and-anti-sublime

Marmot, M. (2017). Post-truth and science. The Lancet, 389(10068), 497-498. https://doi.org/10.1016/S0140$\underline{6736(17) 30207-6}$

Mihailidis, P., \& Viotty, S. (2017). Spreadable spectacle in digital culture: Civic expression, fake news, and the role of media literacies in "post-fact" society. American Behavioral Scientist, 61(4), 441-454. https://doi.org/10.1177/0002764217701217

Nature (2006). Not picture-perfect. Nature: International Journal of Science, 439, 891-892. https://doi.org/10.1038/439891b

Nightingale, S. J., Wade, K. A., \& Watson, D. G. (2017). Can people identify original and manipulated photos of real-world scenes? Cognitive Research: Principles and Implications, 2(30), 1-21. https://doi.org/10.1186/s41235$\underline{017-0067-2}$

Nikolow, S., \& Bluma, L. (2008). Science images between scientific fields and the public sphere. In B. Hüppauf, \& P. Weingart (Eds.). Science images and popular images of sciences (pp. 33-51), New York, NY: Routledge. 
Oksvold, M. P. (2015). Incidence of data duplications in a randomly selected pool of life science publications. Science and Engineering Ethics, 22(2), 487-496. https://doi.org/10.1007/s11948-015-9668-7

Parrish, D., \& Noonan, B. (2009). Image manipulation as research misconduct. Science and Engineering Ethics, 15(2), 161-167. https://doi.org/10.1007/s11948-008-9108-z

Pearson, H. (2005). CSI: Cell biology. Nature: International Journal of Science, 434, 952-953. https://doi.org/10.1038/434952a

Post, S. (2015). Scientific objectivity in journalism? How journalists and academics define objectivity, assess its attainability, and rate its desirability. Journalism, 16(6), 730-749. https://doi.org/10.1177/1464884914541067

Resnik, D. (1998). Problemas y dilemas éticos en la interacción entre ciencia y medios de comunicación / Problems and ethical dilemmas in the interaction between science and the media. Quark: Ciencia, Medicina, Comunicación y Cultura / Quark: Science, Medicine, Communication and Culture, 1998(13), 59-77. Retrieved from http://quark.prbb.org/13/013059.htm

Rosenberger, R. (2009). A case study in the applied philosophy of imaging: The synaptic vesicle debate. Science, Technology \& Human Values, 36(1), 6-32. https://doi.org/10.1177/0162243909337117

Shapin, S. (1994). A social history of truth: Civility and science in seventeenth-century England. Chicago, IL: University of Chicago Press. https://doi.org/10.7208/chicago/9780226148847.001.0001

Shapin, S., \& Schaffer, S. (1985). Leviathan and the air-pump: Hobbes Boyle and the experimental life. Princeton, NJ: Princeton University Press.

Sismondo, S. (2017). Post-truth? Social Studies of Science, 47(1), 3-6. https://doi.org/10.1177/0306312717692076

Tandoc, E. C., Lim, Z. W., \& Ling, R. (2018). Defining "Fake News.” A typology of scholarly definitions. Digital Journalism, 6(2), 137-153. https://doi.org/10.1080/21670811.2017.1360143

Tresch, J. (2007). The daguerreotype's first frame: François Arago's moral economy of instruments. Studies in History and Pbilosophy of Science: Part A, 38(2), 445-476. https://doi.org/10.1016/j.shpsa.2007.03.003

Vargo, C. J., Guo, L., \& Amazen, M. A. (2018). The agenda-setting power of fake news: A big data analysis of the online media landscape from 2014 to 2016. New Media \& Society, 20(5), 2028-

2049. https://doi.org/10.1177/1461444817712086

Wise, M. N. (2006). Making visible. Isis: A Journal of the History of Science Society, 97(1), 75-82. https://doi.org/10.1086/501101

Zwitter, A. (2014). Big data ethics. Big Data \& Society, 1(2), 1-6. https://doi.org/10.1177/2053951714559253

\section{BIOGRAPHY}

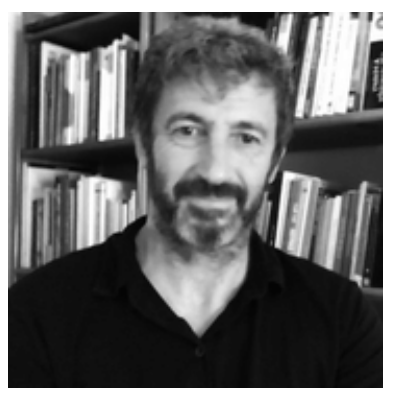

Francisco López-Cantos holds a PhD in Audiovisual Communication and Advertising and Associate Professor at Jaume I University of Castellón (Spain). For more than 20 years, he has been dedicated to teaching and research in the communication field. In his latest works, he has addressed new forms of producing and communicating science to the public within the framework of contemporary visual culture.

Dr. López-Cantos is the Director of Research Group on Communication and Scientific Culture, http://com-science.uji.es/ 